\title{
Otto Ton \& Bubandt Nils (eds) (2010) Experiments in Holism: Anthropology and the Predicaments of Holism. Oxford: Wiley-Blackwell. 336 pages.
}

\author{
Michaela Spencer \\ Northern Institute, Charles Darwin University, Australia / michaela.spencer@cdu.edu.au
}

A strange sense of excitement and unease came over me as I started to read this book. I had not anticipated so many references to STS would appear in an anthropological text. Then when arriving at the chapter 'Worlding the Matsutake Diaspora' by Anna Tsing (2010), I suddenly encountered a reading of the STS canon which I had not considered before. I felt my own assumptions about my discipline being questioned, and that something had come up that STS scholars and anthropologists must discuss; that here were new connections and separations to be made across and between our disciplines. I come back to this feeling in concluding my review, but first I explain my initial put-outness.

Tsing's chapter is one of 12 contributions by leading anthropology scholars collected and curated in this volume. In different ways each of these chapters explores the notion of 'holism' in current anthropological theory and practice, and takes on the task of considering whether this concept - as a frequently critiqued aspect of traditional anthropological work - might continue to play a significant role within the discipline. These authors draw from their own research to examine these concepts in different ways, suggested by the editors as examinations of 'holism in ethnographic practice', and as ways of moving beyond cultural, structural and social wholes as an assumed basis of anthropological work.

In her chapter, Tsing argues that contexting, or 'worlding', is a practice carried out by the ethnographic researcher as they ascribe, often quite incorrect, explanatory frames to research material and experiences. Nonetheless, it is the work of describing this frame, which allows the researcher to develop knowledge claims about empirical research data, through enabling the inclusion of phenomena that at first was not visible or appeared insignificant. To make this point, she differentiates between the significance of 'context' for anthropologists, and STS scholars. She suggests that while anthropologists are always seeking to put things in context, research in science studies denies the existence of context altogether, preferring to work with and through unmediated actor-networks in the making.

This assertion came as a shock. I wanted to exclaim that it was not that this early work in STS denied the existence of context. The point STS attempts to make is that what 'contexts' might be assumed to 'be' is radically contingent.

The way that Tsing makes her claim about the distinction between STS and anthropology is by referring to Michel Callon's (1986) paper on the Scallops of St Brieuc Bay. She recognises that this paper is considered a classic because it shows how actor-networks involving both humans and nonhumans make things happen; but at the same time, she also notes that there are questions that the paper does not ask. For example, why is it that only French scallops and scientists make it onto the list of relevant actors in the network, when at the start of the story the Japanese were also involved? (Tsing, 2010: 48) 
Tsing's point in noticing the omission of Japanese scallops and scientists within Callon's story, is that empirical research texts only narrate events as they appear as significant within someone's judgement of what counts as an appropriate whole. In the case, she suggests, that Callon's version of 'worlding' fails because this decision to include the French - but not the Japanese - was never noted or explained within the text.

This was interesting, because for me this paper has always been masterly in the way it takes on the assumption embedded in (probably still) prevailing philosophies of science that scientific inquiry involves the discovery of facts about a passive external world out there waiting to be known. By bringing non-humans into the picture as active participants of scientific knowledge production, previously unassailable claims of scientific objectivity began to crumble. As such, this paper offered an intervention into an epistemo-political context, one in which such an intervention was desperately needed.

Now, should I ever have occasion to negotiate with an anthropologist about this in some future interdisciplinary project, my assertion might be, that in writing this paper Callon was certainly 'worlding', but not in the sense that anthropology 'worlds'. It was not Callon's intention to produce a comprehensive account of a specific geographically bounded instance of knowledge making. Such a task would have necessarily left unexamined the associative and descriptive task of producing sociality, locality and scale within knowledge work. And would have short-circuited attempts to show science might recognise contingency within its own practices, and therefore disrupt prevailing objectivist narratives.

My aim in having such a conversation with some imagined future anthropological colleague is to begin to notice a radical difference between contexts: assumed global geographies of inclusion and exclusion here, and political orders emergent in epistemic practices there. Such a provocation to thought, contains within it the capacity to engender recognition of difference. That is what seems to be key to recommending this book outside of anthropology.
At the start of the book the editors talk about the motivations for this inquiry into holism, a key tenet of anthropological research throughout the $20^{\text {th }}$ Century. They tell how a number of Scandinavian anthropology departments initiated a series of events aimed at exploring anthropology's past failings and its current practice. The aim was to become better able to support new anthropology graduate students who, it is assumed, will inevitably find themselves working with ethnographic methods that are continually changing, and in building careers through interdisciplinary collaborations.

As an STS scholar I was dazzled and enthralled by the vibrant descriptions of people, places and cosmologies. I was also impressed by the capacity for various groups of scholars in the discipline of anthropology to generate such a detailed and thorough exploration of a concept and methodological practice, at a time when far more tangible research outputs are often required, and the academy in general seems to have abandoned its support of disciplines as a core part of its being.

However, I was also surprised that amidst the very many versions of holism - past and present - that appear in this text, there were none that stepped beyond a consideration of holism as an epistemological matter; that is, as a means for producing better or worse empirical accounts of diverse external realities. Remembering my own beginning days as a PhD student, it was being sensitised to the ways in which wholes and parts are proposed as an ontological multiplicity in STS that helped me to recognise multiple natures appearing in the patches of bush where I was doing my fieldwork. Helen Verran's (2001) work with number, and Annemarie Mol's (2002) work with bodies, both find ways to show and work with ontological multiplicity by projecting new virtual wholes within which questions of what is known, by whom and in what way, are able to figure within analysis. It was under the guidance of such approaches, that within my own research work I was able to begin the process of charting a new nature coming to life under the influence of neoliberalism.

Paradoxically the book succeeds in being of interest beyond anthropology precisely because it is solely interested in anthropology. In looking 
for ways to support new anthropologists to move into interdisciplinary collaborations, the rich detail provided in the very different chapters of this collection help to highlight both the potential and the limits of disciplinary practice, and in so doing provides much fodder for discussion between anthropologists, and their collaborators. It is an exemplification of such a challenging engagement that I have presented here in this review, and no doubt many more lengthy and more elaborated debates will emerge out of reading of this text, both by scholars of anthropology and other disciplines.

\section{References}

Callon M (1986) Some elements of a sociology of translation: domestication of the scallops and the fishermen of St Brieuc Bay. In: Law J (ed) Power, action and belief: a new sociology of knowledge? London: Routledge, 196-223.

Mol A (2002) The body multiple: Ontology in medical practice. Durham \& London: Duke University Press.

Tsing A (2010) Worlding the Matsutake Diaspora: Or, can Actor-Network Theory Experiment with Holism? In: Otto T \& Bubandt N (eds) Experiments in Holism: Anthropology and the Predicaments of Holism. Oxford: Wiley-Blackwell.

Verran H (2001) Science and an African logic. Chicago \& London: University of Chicago Press. 